\title{
Pemberdayaan Masyarakat Dalam Mewujudkan Kabupaten Banyuwangi Sehat
}

\author{
Nur Anim Jauhariyah', Nurul Inayah ${ }^{2}$ \\ Fakultas Ekonomi dan Bisnis Islam, IAI Darussalam Blokagung Banyuwangi \\ Email: ${ }^{1}$ animjauhariyah@gmail.com, ${ }^{2}$ ninailzam2015@gmail.com
}

\begin{abstract}
Healthy Regency / City is an effort to create a district / city condition that is clean, comfortable, safe and healthy for residents to live in, which is achieved through implementing several integrated arrangements and activities agreed upon by the community and local government. Banyuwangi Regency has participated in this activity which started in 2011 ago. The District Forum in Banyuwangi Regency, which has been formed with the support of the Pokja Desa / healthy kelurahan, has carried out activities according to the 6 indicators that are currently being followed by Banyuwangi Regency. Coaching activities are carried out in incidental meetings during forum visits to the District. Activities during the Covid 19 pandemic in 2020 were more dominated by social activities such as distributing masks, hand sanitizers, spraying disinfectants in public places as an effort to break the chain of transmission of the Covid 19 virus in Banyuwangi Regency.
\end{abstract}

Keywords: Order, Healthy District, Covid 19 pandemic

\section{Pendahuluan}

Gambaran umum wilayah Kabupaten Banyuwangi merupakan sebuah data dasar yang digunakan sebagai acuan dalam penyusunan perencanaan pembangunan kesehatan yang evidence based, sehingga perencanaan program maupun kegiatan bidang kesehatan sesuai dengan kebutuhan masyarakat dan kondisi faktual di wilayah Kabupaten Banyuwangi. Gambaran umum ini menguraikan tentang letak geografis, administratif dan beberapa informasi umum lainnya. Selain itu juga mengulas beberapa faktor yang berpengaruh terhadap kesehatan dan faktor-faktor lainnya misalnya kependudukan, ekonomi, dan sosial budaya. 
Secara astronomis Kabupaten Banyuwangi terletak diantara $7^{\circ} 43^{\prime}$ $8^{\circ} 46^{\prime}$ Lintang Selatan dan $113^{\circ} 53^{\prime}-114^{\circ} 38^{\prime}$ Bujur Timur. Kabupaten Banyuwangi memiliki panjang garis pantai sekitar 175,8 km, serta Pulau sejumlah 10 buah. $^{1}$

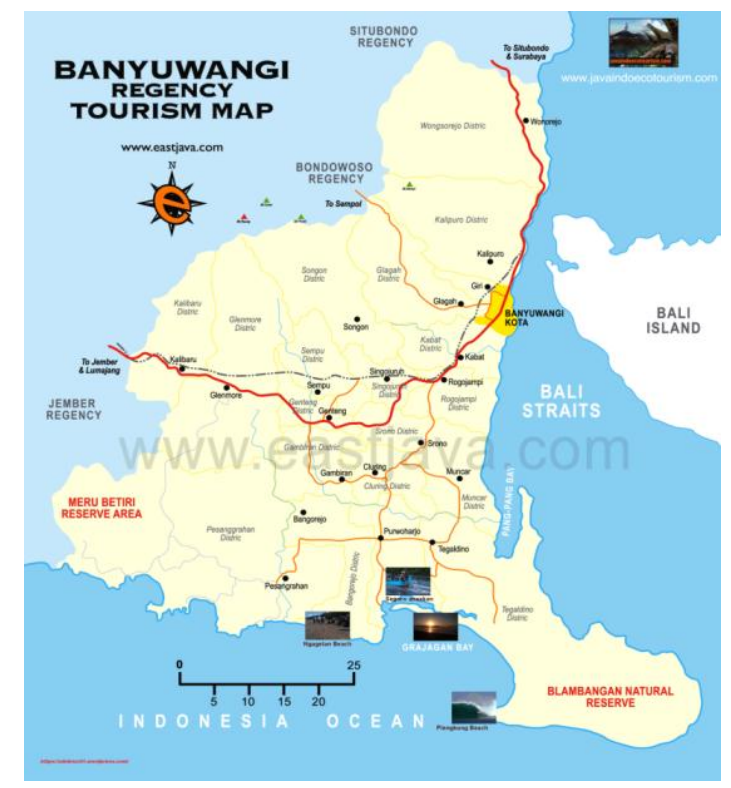

\section{Gambar 1. Peta Wisata Kabupaten Banyuwangi (Sumber: BPS Kabupaten Banyuwangi, 2020)}

Kabupaten/Kota Sehat merupakan suatu kondisi kabupaten/kota yang bersih, nyaman, aman dan sehat untuk dihuni penduduk, yang dicapai melalui terselenggaranya penerapan beberapa tatanan dan kegiatan yang terintegrasi yang disepakati masyarakat dan pemerintah daerah. ${ }^{2}$

${ }^{1}$ Jauhariyah, N. (2019). Halal Friendly Tourism Policy In Banyuwangi. Proceedings of Annual Conference for Muslim Scholars, 3(1), 81-89. Retrieved from http://proceedings.kopertais4.or.id/index.php/ancoms/article/view/222

2 Peraturan Bersama Menteri Dalam Negeri Dan Menteri Kesehatan Nomor 34 tahun 2005 nomor: 1138/MENKES/PB/VIII/2005 Tentang Penyelenggaraan Kabupaten/Kota Sehat Dengan Rahmat Tuhan Yang Maha Esa Menteri Dalam Negeri Dan Menteri Kesehatan. Diakses pada 20 Agustus 2019 http://jdih.surakarta.go.id/jdihsolo/proses/produkhukum/file/2219PERMEN_34_2005_ PENERBIT_PDF\#: :text=Pengertian-

,1.,disepakati\%20masyarakat\%20dar\%2C\%20pemerintah\%20daerah. 2005:444

Pemberdayaan Masyarakat Dalam Mewujudkan Kabupaten Banyuwangi Sehat

Nur Anim Jauhariyah, Mahmudah, Nurul Inayah 
Kabupaten sehat mewujudkan kawasan Sehat yang merupakan suatu kondisi wilayah yang bersih, nyaman, aman dan sehat bagi pekerja dan masyarakat, melalui peningkatan suatu kawasan potensial dengan kegiatan yang terintegrasi yang disepakati masyarakat, kelompok usaha dan pemerintah daerah. Penghargaan yang diberikan oleh pemerintah untuk penyelenggaran kabupaten/kota sehat disebut dengan Swasti Saba yang diberikan oleh pemerintah kepada masyarakat melalui Bupati/Walikota atas keberhasilan dalam menyelenggarakan Kabupaten/Kota Sehat.

Kabupaten Banyuwangi telah melaksanakan Kabupaten Sehat dimulai pada tahun 2011 dengan memperoleh penghargaan pertama yaitu Swasti Saba Padapa pada Tahun 2015, Wiwerda Tahun 2017, dan penghargaan tertinggi Wistara pada Tahun 2019. Penyelenggaraan penilaian/ verifikasi dilaksanakan pada tahun genap untuk tingkat provinsi dan tahun genap untuk tingkat nasional.

Sektor pertanian merupakan sektor yang masih memberikan kontribusi bagi pertumbuhan ekonomi di Banyuwangi. Hasil analisis AHP untuk mencari solusi kebijakan dari analisis data primer menunjukkan bahwa sektor tersebut masih sangat optimis terhadap potensi dan berkembang sesuai dengan tahun analisis Banyuwangi masih optimis pada sektor pertanian, disusul sektor perhotelan melihat potensi pariwisata di Banyuwangi. masih asri dan bersih, berpotensi dioptimalkan untuk menambah PAD Banyuwangi. $^{3}$

Potensi sektor basis di Kabupaten Banyuwangi hasil analisis Tipologi klassen menunjukkan sektor yang dikategorikan sebagai sektor maju dan tumbuh pesat (sektor prima) adalah Sektor Pertanian dan sektor yang

3 Jauhariyah, Nur Anim dkk. Disparitas Antar Kecamatan Dan Strategi Pembangunan Ekonomi di Kabupaten Banyuwangi. diakses 16 Agustus 2019. http://jurnal.unissula.ac.id/index.php/cbam/article/view/170/0 
terbelakang adalah sektor Industri Pengolahan, Perdagangan, Hotel dan Restoran, Pengangkutan dan Komunikasi, dan Jasa-jasa. ${ }^{4}$

Pemberdayaan masyarakat dalam menjaga dan mewujudkan kehidupan dan lingkungan yang bersih, nyaman, aman dan sehat apalagi pada masa pandemic sangat penting sebagai upaya pemutusan rantai penularan virus covid 19 di Kabupaten Banyuwangi. oleh karena itu berbagai upaya dilakukan pemerintah daerah bekerja sama dengan masyarakat untuk menggiatkan masyarakat dalam menjaga kebiasaan baru di kehidupan sehari-hari dengan menerapkan 3M : Memakai Masker, Menjaga Jarak, dan Mencuci tangan dengan sabun.

\section{Metode}

Pemberdayaan ini menggunakan pendekatan Participatory Action Research (PAR). ${ }^{5}$ Berbagai endapan permasalahan tersebut perlu adanya penggalian kembali dan dicairkan serta dicari titik pangkal permasalahannya. Pada uraian ini akan dipaparkan beberapa aksi yang dilakukan oleh tim pendamping sebagai langkah awal untuk menggali dan mencairkan endapanendapan permasalahan yang ada di 25 Kecamatan di Kabupaten Banyuwangi

\section{Hasil dan Diskusi}

Prosentase kecamatan di Banyuwangi yang mengikuti program = 90,78\%. Pada Tahun 2016 Kabupaten Banyuwangi terdiri atas 24 Kecamatan, kemudian pada Tahun 2017 terjadi pemekaran Kecamatan

4 JAUHARIYAH, Nur Anim. Kebijakan Pengentasan Kemiskinan Melalui Kajian Potensi Sektor Basis Di Kabupaten Banyuwangi. Jurnal Darussalam: Jurnal Pendidikan, Komunikasi dan Pemikiran Hukum Islam, [S.l.], v. 7, n. 1, p. 112-126, sep. 2015. ISSN 2549-4171. Available at: <http://ejournal.iaida.ac.id/index.php/darussalam/article/view/54>. Date accessed: 15 dec. 2020.

5 INAYAH, Nurul et al. Pemberdayaan Masyarakat Dalam Usaha Peningkatan Pendapatan Keluarga Sejahtera (UPKKS). LOYALITAS, Jurnal Pengabdian Kepada Masyarakat, [S.I.], v. 2, n. 1, p. 112-123, may 2019. ISSN 2621-4687. Available at: <http://ejournal.iaida.ac.id/index.php/loyal/article/view/409>. Date accessed: $15 \mathrm{dec}$. 2020.

Pemberdayaan Masyarakat Dalam Mewujudkan Kabupaten Banyuwangi Sehat 
Rogojampi menjadi Kecamatan Blimbingsari, maka jumlah kecamatan di Banyuwangi menjadi 25 Kecamatan. Dari 25 Kecamatan tersebut yang sudah ter SK kan mengikuti program sebanyak 23 Kecamatan, yaitu:

1) Kecamatan Banyuwangi;

2) Kecamatan Glagah;

3) Kecamatan Kalipuro;

4) Kecamatan Licin;

5) Kecamatan Rogojampi;

6) Kecamatan Songgon;

7) Kecamatan Srono;

8) Kecamatan Cluring;

9) Kecamatan Gambiran;

10) Kecamatan Pesanggaran;

11) Kecamatan Siliragung;

12) Kecamatan Bangorejo;

13) Kecamatan Purwoharjo;

14) Kecamatan Sempu;

15) Kecamatan Genteng;

16) Kecamatan Tegalsari;

17) Kecamatan Glenmore;

18)Kecamatan Giri;

19) Kecamatan Blimbingsari;

20)Kecamatan Muncar;

21)Kecamatan Singojuruh;

22)Kecamatan Tegaldlimo;

23)Kecamatan Kabat.

Jumlah desa/kelurahan di Kabupaten Banyuwangi terdapat 217 Desa/Kelurahan. Dari 23 Kecamatan yang mengikuti program terdiri atas 197 Desa/ kelurahan, sehingga prosentasenya 98,78\% dari total 
LOYALITAS

Yutral Dengabatian Xepada Masjarakat

Volume III Nomor 2 November 2020
ISSN : 2621-4679 (print)

ISSN : 2621-4687 (online)

desa/kelurahan se Kabupaten Banyuwangi. Keseluruhan desa/kelurahan tersebut telah dilengkapi dengan SK Kepala Desa/Lurah. Terlampir Foto dokumen SK Pokja Kelurahan Temenggungan Kecamatan Banyuwangi dan Foto dokumentasi saat pembentukan Pokja Desa Sehat di Kecamatan Genteng.

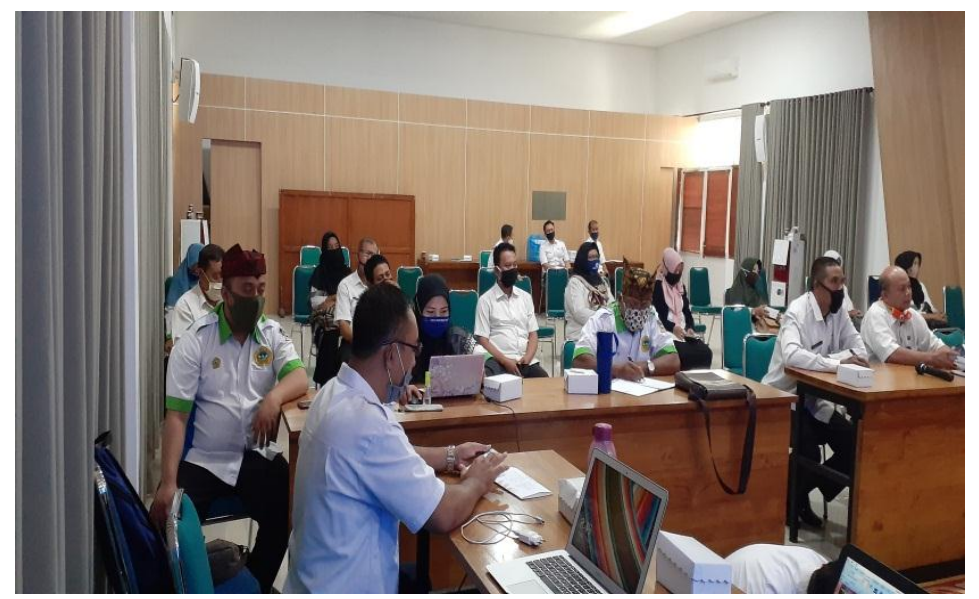

\section{Gambar 2. Pemantapan Forum Komunikasi Kelurahan/Desa Sehat di Kantor Pemda Kabupaten Banyuwangi}

(Sumber: Dokumentasi, 2020)

Cakupan kecamatan skala kota terdiri atas 4 Kecamatan yaitu, Kecamatan Banyuwangi, Giri, Glagah dan Kalipuro. Seluruh kecamatan sudah mengikuti program dengan bukti SK terlampir. Kota Banyuwangi terdiri atas 24 Kelurahan yang keseluruhannya telah mengikuti program dengan telah terbentuknya Pokja Kelurahan Sehat.

Enam tatanan yang diikuti Kabupaten Banyuwangi dalam verifikasi kabupaten/kota sehat tingkat provinsi maupun nasional, sesungguhnya adalah cermin kegiatan berbagai satker tim teknis pembina kabupaten sehat tingkat kabupaten Banyuwangi. Capaian realisasi kegiatan tim pembina teknis terlampir. 

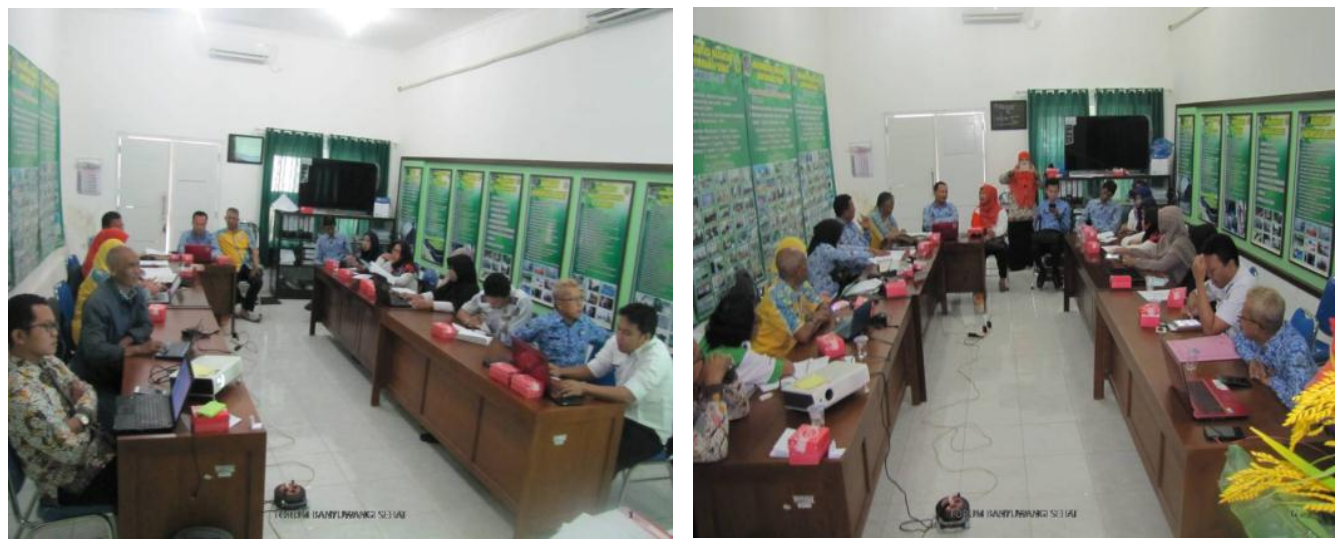

Gambar 3. Rapat Evaluasi Kinerja Tim FBS Bersama Pembina Teknis (Sumber: Dokumentasi, 2020)

Dukungan Pemda berupa;

a. SK Bupati Banyuwangi Nomor 188/42/KEP/429.011/2016 Tahun 2016 tentang tim pembina teknis kabupaten /kota sehat kabupaten Banyuwangi (Lampiran 2.A).

b. SK Bupati Banyuwangi Nomor 188/184/KEP/429.011/2015 Tahun 2015 Tanggal 24 Maret 2015 tentang Forum Banyuwangi Sehat.

Terbentuknya Forum Banyuwangi Sehat didasarkan pada surat keputusan Bupati Banyuwangi No. 188/564/KEP/429.011/2011 Tanggal 12 Juli 2011 junto 188/293/KEP/429.011/2013 yang kepengurusannya terdiri dari unsur masyarakat, pemerintah, swasta, perguruan tinggi dan media massa.

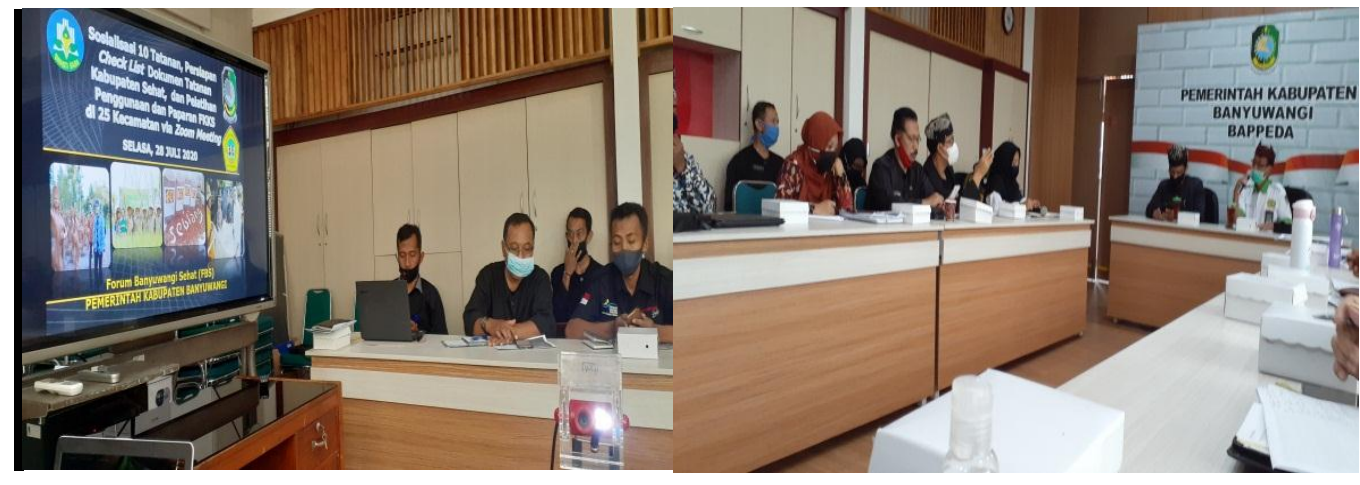

Gambar 4. Pembinaan Forum Komunikasi Kecamatan Sehat Oleh Pembina Teknis dan Forum Banyuwangi Sehat (Sumber: Dokumentasi, 2020) 
Regulasi yang mendukung tatanan sebagai berikut:

1. Perbub No. 29 Tahun 2014 tentang kawasan terbatas merokok

2. Perbub No. 46 tahun 2013 tentang Shodaqoh Oksigen

3. SK Kepala Dinas Kebudayaan dan Pariwisata tentang Kelompok Sadar Wisata (POKDARWIS) di masing-masing kawasan daya tarik wisata

4. Perda No 09 tahun 2013 tentang pengelolaan sampah rumah tangga dan sampah sejenis rumah tangga.

5. Perbub No 26 tahun 2014 tentang Petunjuk Pelaksanaan Peraturan Daerah Kab. Banyuwangi No.9 Tahun 2013 Tentang Pengelolaan Sampah Rumah Tangga Dan Sampah Sejenis Sampah Rumah Tangga.

6. Perbup Nomor 42 Tahun 2016 Tentang Pengawasan Dan Pengendalian Kesehatan Lingkungan Pada Fasilitas Kesehatan, Lingkungan Perkantoran, Industri Dan Tempat-tempat Umum.

7. Peraturan Bupati Banyuwangi Nomor 9 Tahun 2016 Tentang Kebijakan Dan Strategi Daerah Dalam Pengembangan Sistem Penyediaan Air Minum Kabupaten Banyuwangi.

8. Peraturan Daerah Kabupaten Banyuwangi Nomor 1 Tahun 2017 Tentang Desa Wisata

Seluruh Tatanan Yang Diambil Ada Penghargaannya

1) Tatanan Kawasan Sarana Prasarana Permukiman Sehat mendapatkan penghargaan: Swasti saba Wistara Tahun 2019;

2) Tatanan Kehidupan Masyarakat Sehat Yang Mandiri mendapatkan penghargaan

a. Swasti saba Wistara Tahun 2019;

b. Top 25 Inovasi Pelayanan Publik Jatim, yaitu program Smart Kampung dan "Kembali ke ASI"; 
c. Penghargaan "The Most Interested Innovation" oleh forum Open Government Partnership (OGP) Asia-Pacific Regional Meeting di Seoul, Korea Selatan November Tahun 2018;

d. Penghargaan "Program Kesehatan Gancang Aron" Tahun 2018;

e. Penghargaan 'Kabupaten Layak Anak' Tahun 2018

3) Tatanan Kawasan Tertib Lalu Lintas Dan Layanan Transportasi mendapatkan Penghargaan mendapatkan Penghargaan:

a. Operasi Keselamatan Semeru Tahun 2018;

b. Wahana Tata Nugraha Tahun 2019;

4) Tatanan pariwisata sehat mendapatkan Penghargaan:

a. Penghargaan Tingkat ASEAN, ASEAN Tourism Association (ASEANTA). Kota Bersih Tingkat ASEAN ASEAN Clean Tourist City Standard Award Tahun 2018;

b. Penghargaan Indonesia Smart Nation Award (ISNA) 2018

c. Marketeers of The Year kategori Public Service of The Year tingkat Jawa Timur penghargaan di tiga sektor layanan publik, yakni pariwisata, pengembangan desa, dan kesehatan Tahun 2018;

d. Kabupaten Banyuwangi ditetapkan sebagai salah satu dari kawasan Taman Bumi atau Geological Park (Geopark) Nasional 2018.

e. Penghargaan Anugerah Wisata Jawa Timur Tahun 2019 sebagai daerah yang memiliki komitmen dan kepedulian yang tinggi dalam mengembangkan sektor wisata.

f. Indonesia's Attractives index 2019 oleh menteri pariwisata.

5) Tatanan Kawasan Industri dan Perkantoran Sehat Penghargaan

a. Anugerah Pangripta Nusantara Tahun 2018, Penghargaan diberikan karena Banyuwangi dinilai berprestasi dalam perencanaan dan pecapaian pembangunan.

b. Penghargaan sebagai "Kabupaten Terinovatif" dalam kompetisi Innovative Government Award (IGA) 2018. 
c. Kepolisian Resort (Polres) Banyuwangi menerima penghargaan di bidang pembangunan Zona Integritas menuju Wilayah Bebas dari Korupsi (WBK).

d. Penghargaan diajang kompetisi pelayanan public (Kovablik) Otonomi Awards.

e. Kabupaten Banyuwangi meraih penghargaan pembangunan daerah (PPD).

f. Banyuwangi menerima penghargaan Top 10 Penerimaan Pengaduan Pelayanan Publik dari Kementerian Pemberdayaan Aparatur Negara dan Reformasi Birokrasi (Kemenpan-RB).

g. Pemkab Banyuwangi kembali meraih nilai A dalam penilaian Sistem Akuntabilitas Kinerja Pemerintah (SAKIP) 2018.

h. Penghargaan Mal Pelayanan Publik (Mal PP) kepada Bupati Banyuwangi Abdullah Azwar Anas di Manado.

i. TOP 99 Inovasi Pelayanan Publik Tahun 2019.

j. Akuntabilitas Kinerja Instansi Pemerintah, Sistem Akuntabilitas Kinerja Instansi Pemerintah (SAKIP) Tahun 2019.

k. Sistem pemerintahan berbasis elektronik (SPBE) Tahun 2019;

1. Satya Lencana Karya Bhakti Praja Nugraha Tahun 2019;

m. Sistem Akuntabilitas Kinerja Instansi Pemerintah (SAKIP) Tahun 2020;

n. Maturitas Penyelenggara Sistem Pengendalian Internal Pemerintah (SPIP) Level 3 Tahun 2020.

6) Tatanan Ketahanan Pangan dan Gizi mendapatkan Penghargaan:

a. Satya Lencana Karyabhakti Praja Nugraha 2017;

b. Satya Lencana Satya Wirakarya;

c. Laporan Penyelenggaraan Pemerintahan Daerah (LPPD);

d. Penghargaan dari Gubernur Jawa Timur Soekarwo di Hari Pangan Sedunia Tahun 2108; 
e. P4S Sirtanio sebagai Pusat Pelatihan Pertanian dan Perdesaan Swadaya (P4S) Kelas Pratama Berprestasi Tingkat Nasional Tahun 2018

f. Kelompok Tani "Pucang Sari”, Desa Jambewangi - Kecamatan Sempu mendapatkan Juara 1 Agribisnis Tanaman Pangan dan Hortikutura Tingkat Provinsi Jawa Timur tahun 2018

g. Kelompok Masyarakat "Agung Lestari”, Desa Rejoagung Kecamatan Srono mendapatkan Juara 1 Anty Poverty Program Bidang Pertanian Lomba Agribisnis Tanaman Pangan dan Hortikutura Tingkat Provinsi Jawa Timur Tahun 2018

h. KEP "Sari Lestari", Desa Kumendung - Kecamatan Muncar mendapatkan Juara 1 Kelembagaan Ekonomi Petani Berprestasi Kategori Kelembagaan Ekonomi Petani (KEP) Penghargaan Bidang Penyuluhan Tingkat Provinsi Jawa Timur 2018

i. Drh. Luluk Wulandari, petugas Medik Veteriner dari Puskesmas Gambiran sebagai Juara 1 Lomba Optimalisasi Dokter Hewan Puskesmas Tingkat Provinsi Jawa Timur Tahun 2018

j. Dodik Yulianto, Sebagai Petugas Paramedik Veteriner dari Puskesmas Gambiran sebagai Juara III Lomba Optimalisasi Dokter Hewan Puskesmas Tingkat Provinsi Jawa Timur Tahun 2018

k. Pencapaian Sertifikasi Internasional Padi Organik dan Control Union dan USAID untuk padi organik produksi P4S Sirtanio, Kecamatan Singojuruh

1. Pencapaian Sertifikasi Internasional Padi Organik dari LeSOS kepada Kelompok Tani Mawar Sari, Desa Jambewangi, Kecamatan Sempu.

m. Pencapaian Sertifikasi Internasional Padi Organik dari LeSOS kepada Kelompok Tani Ketangi Santosa, Desa Kalibaruwetan, Kecamatan Sempu 
n. Pencapaian Sertifikat Gula Merah (Aren) Organik dari LeSOS oleh Kelompok Tani “Bukit Hijau”, Desa Kluncing, Kecamatan Licin

o. Terdaftarnya Jeruk Varietas Jemali dari Kabupaten Banyuwangi di Kementerian Pertanian.

p. Terdaftarnya Jeruk Verietas Si Nona A3 dari Kabupaten Banyuwangi di Kementerian Pertanian

q. Terdaftarnya Pisang Varietas Kelip dari Kabupaten Banyuwangi di Kementerian Pertanian

r. Terdaftarnya Sawo Varietas Blambangan dari Kabupaten Banyuwangi di Kementerian Pertanian.

s. Inovasi Pengendalian Inflasi (pengembangan ekonomi pedesaan melalui sinergi badan usaha milikdesa dan perum BULOG Tahun 2019 diadakan oleh Kementerian Dalam Negeri.

Forum Banyuwangi sudah membentuk Forum Komunikasi di 23 Kecamatan

Rencana jangka panjang:

Meraih Penghargaan Nasional Wistara (Enam Tatanan) yaitu :

1) Tatanan Kawasan Pemukiman, Sarana dan Prasarana Sehat.

2) Tatanan Kehidupan Masyarakat yang sehat dan Mandiri.

3) Tatanan Kawasan Pariwisata Sehat.

4) Tatanan Kawasan Tertib Lalu Lintas dan Pelayanan Transportasi.

5) Tatanan Kawasan Industri dan Perkantoran Sehat.

6) Tatanan Ketahanan Pangan dan Gizi. 
LOTALITAS

Yurnal Dengalodian Xepada Masyaralkat

Volume III Nomor 2 November 2020
ISSN : 2621-4679 (print)

ISSN : 2621-4687 (online)
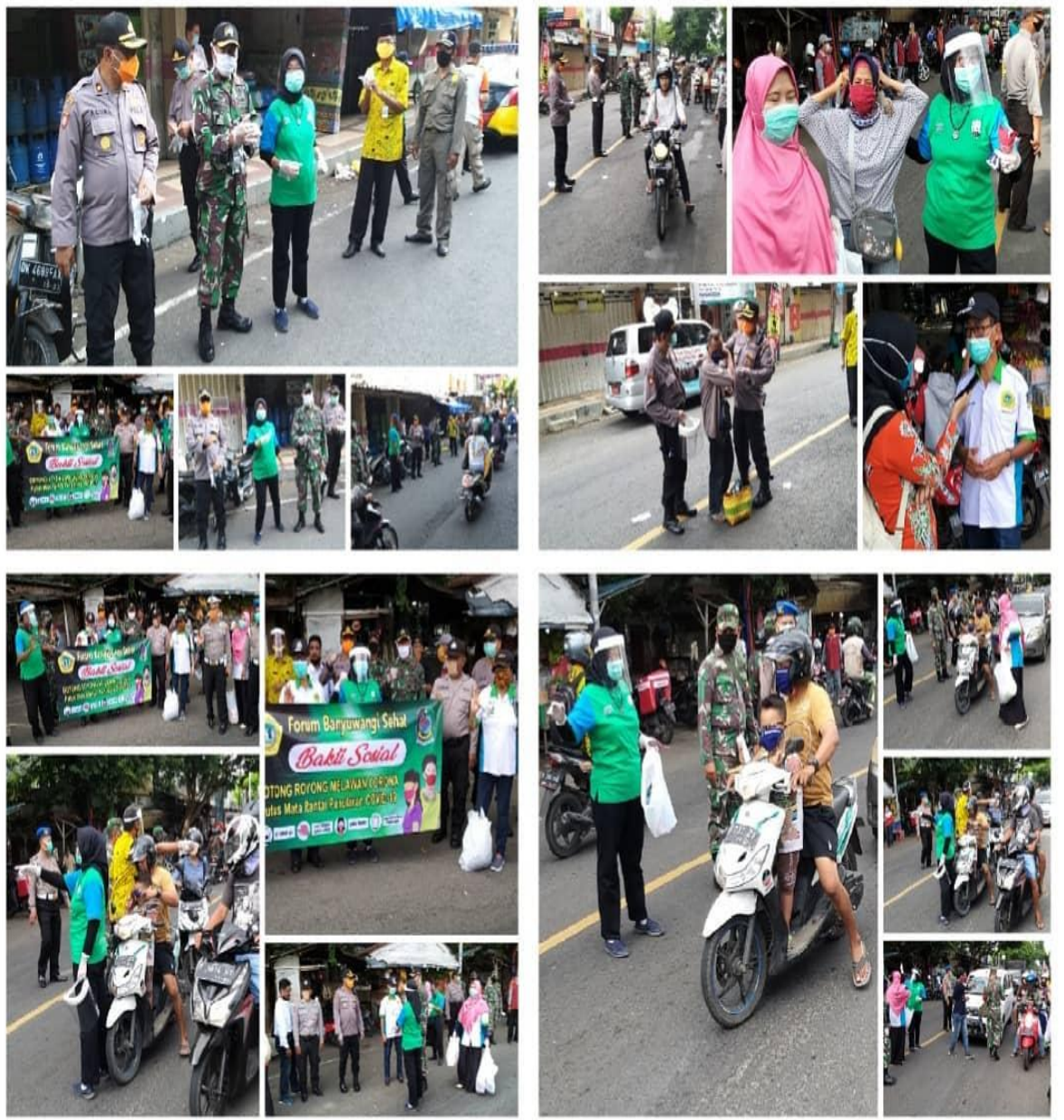

Gambar 5 Forum Banyuwangi Sehat dan Forum Komunikasi di
Kecamatan Rogojampi mengadakan Baksos Pembagian Masker (Sumber: Dokumentasi, 2020)

Forum bersama Satker terkait sering terlibat dalam berbagai kegiatan yang terkait dengan tatanan, misalkan rapat koordinasi, pembinaan, seminar, penjurian lomba dan pemantauan titik pantau tatanan lomba. Dimasa pandemic kegiatan didominasi dengan kegiatan sosial pembagian masker, penyemprotan disinfektan, dan handsanitasier. 


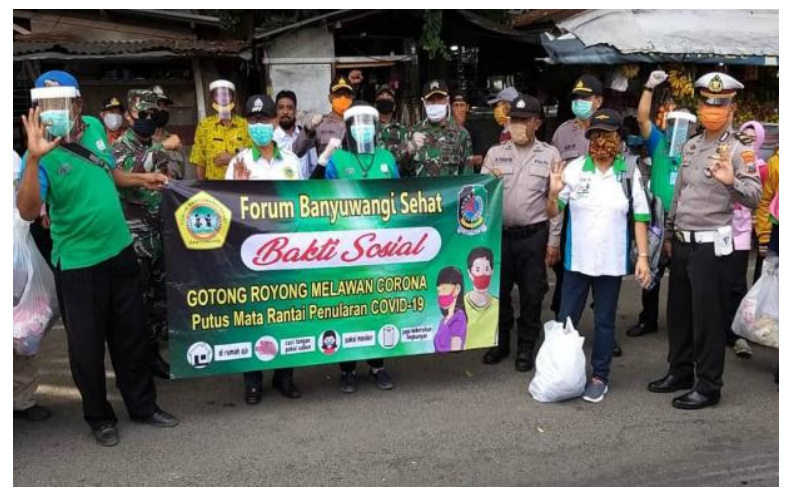

Gambar 6. Keterlibatan Anggota Forum Dalam Kegiatan Gotong Royong Memutus Rantai Penularan Covid 19 (Sumber: Dokumentasi, 2020)

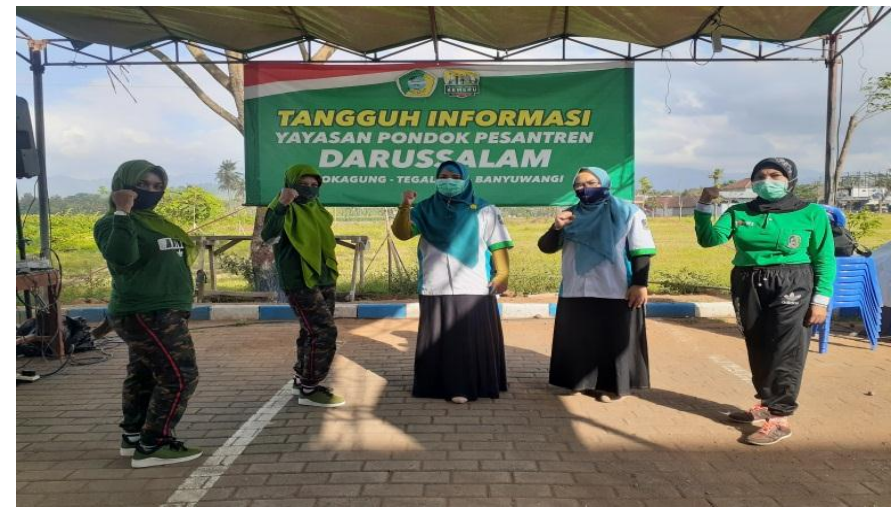

Gambar 7. Keterlibatan Anggota Forum Dalam Kegiatan Relawan Covid 19 dengan Forum Komunikasi Kecamatan Sehat dan Dinas Kesehatan (Sumber: Dokumentasi, 2020)

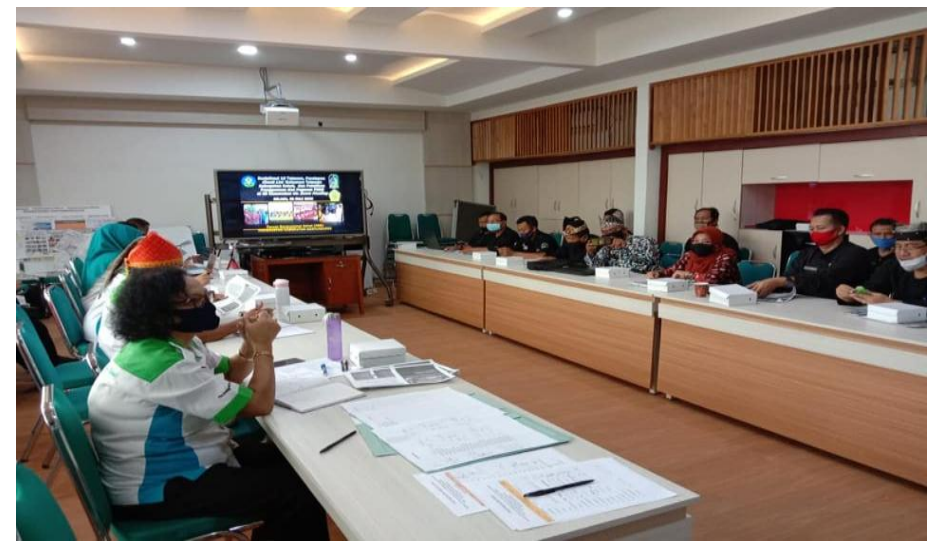

Gambar 8. Sinergitas Forum dan Pembina dalam Memberikan Pembinaan Kepada Forum Komunikasi Kecamatan (Sumber: Dokumentasi, 2020)

Pemberdayaan Masyarakat Dalam Mewujudkan Kabupaten Banyuwangi Sehat Nur Anim Jauhariyah, Mahmudah, Nurul Inayah 

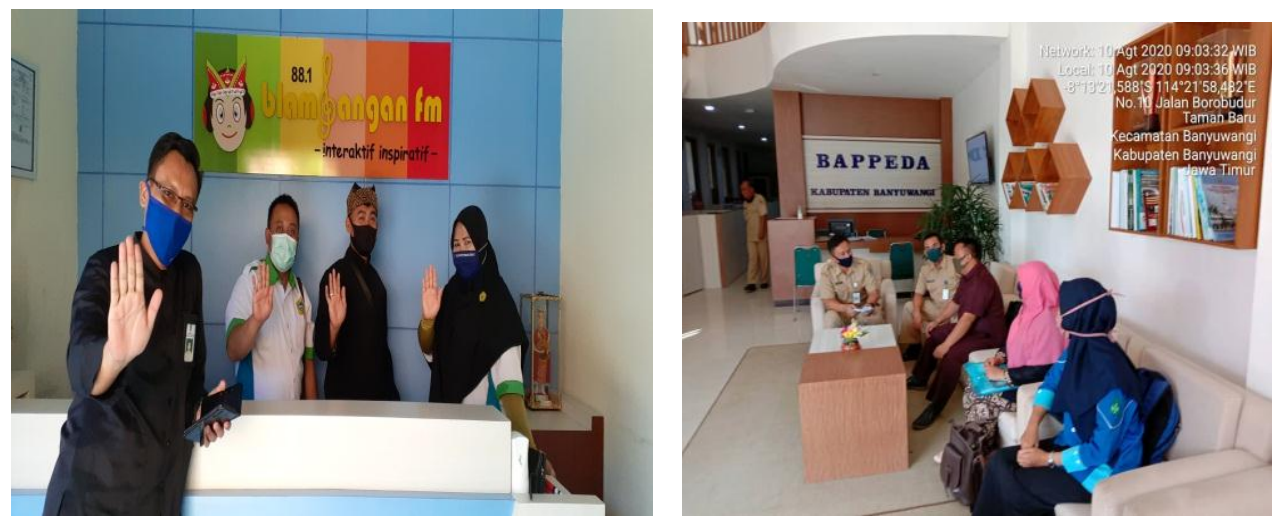

Gambar 9. Keterlibatan Anggota Forum Dalam Talkshow Radio \& Kegiatan Audiensi Dengan Jajaran Pemerintah Kabupaten Banyuwangi (Sumber: Dokumentasi, 2020)

Kegiatan forum sesuai dengan rencana kerja Tahun 2019-2020 telah $100 \%$ terealisir, secara umum capaian rencana tersebut terdokumentasi dalam display data sebagaimana terlampir.

Kegiatan masyarakat (gerakan masyarakat) yang ada di Kabupaten Banyuwangi yang mendukung Kabupaten Kota Sehat, antara lain:
a. Merdeka Dari Sampah Banyuwangi
b. Bank Sampah Banyuwangi
c. Banyuwangi Eco School
d. Gerakan Hidup Bersih dan Sehat
e. Talk Show Radio
f. Pengelolaan Sampah Organik Pokmas Maskot
g. Pemanfaatan Sampah Organik dan Anorganik
h. Program Kali Bersih (Prokasih)
i. Harga PAS (Harapan Keluarga Peduli Anak Sejak Dini)
j. TOKCER (Anak Tumbuh Optimal Berkualitas dan Cerdas)
k. Gemar Makan Ikan (Gemarikan)
l. Sedekah Oksigen
m. Desa Berseri
n. STBM dengan Gerakan GGJ (Gemari Gunakan Jamban) 
o. Prokalbekong (Program Kali Bersih Bebas Bokong)

p. Program 'Inspektur Cilik'

q. Garda Ampuh

r. Smart Kampung

s. Program 'Rantang Kasih', Makanan Bergizi Tiap Hari Untuk Lansia.

t. 'Banyuwangi Mall' Pelayanan Satu Atap

u. 'E-Village Budgeting'

v. Program Kesehatan Gancang Aron

w. Program Kabupaten Layak anak

Dan masih banyak lagi inovasi yang diluncurkan oleh Pemerintah Banyuwangi dan masyarakat dengan tujuan untuk mendukung Banyuwangi semakin sehat dan sejahtera.

Forum Kecamatan di Kabupaten Banyuwangi yang telah dibentuk dengan didukung oleh Pokja Desa/kelurahan sehat, telah melakukan kegiatan sesuai dengan indikator 6 tatanan yang saat ini di ikuti oleh Kabupaten Banyuwangi. Dokumentasi kegiatan terlampir. Kegiatan pembinaan dilakukan dalam pertemuan insidentil ketika ada kunjungan forum ke Kecamatan. Kegiatan di masa pandemi covid 19 tahun 2020 lebih didominasi pada kegiatan sosial.

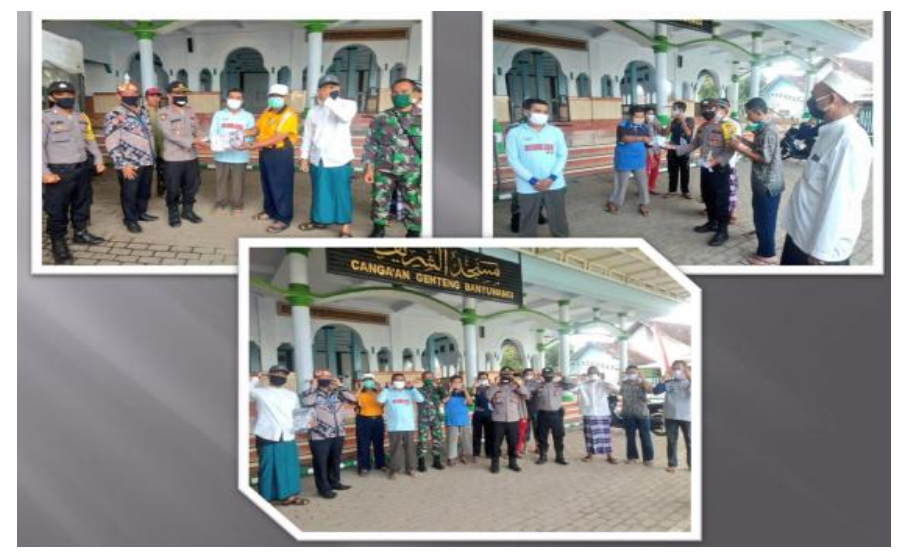

\section{Gambar 10. Dokumen Kegiatan Forum Kecamatan Genteng Dalam Memberikan Bantuan Masker Ke Masjid Sekitar (Sumber: Dokumentasi, 2020)}




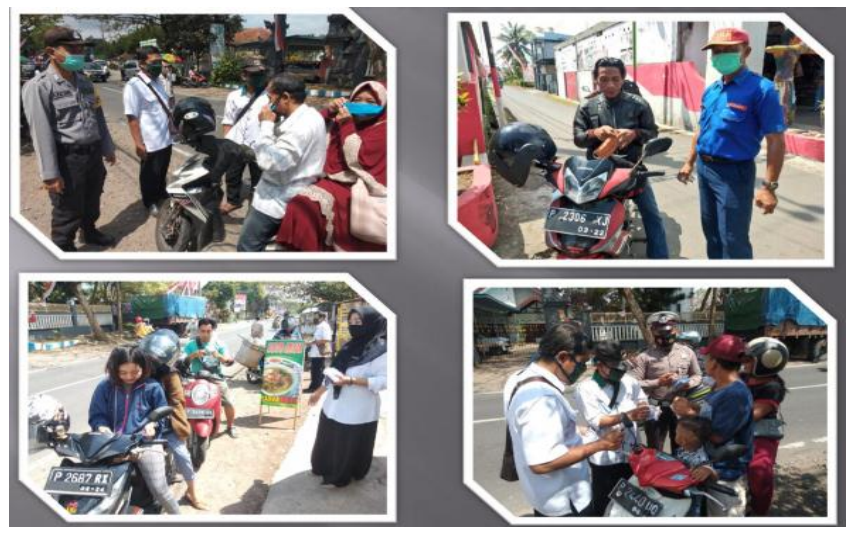

\section{Gambar 11. Dokumen Kegiatan Forum Kecamatan Genteng Dalam Memberikan Bantuan Masker Kepada Pengguna Jalan}

Pokja Desa/Kelurahan sehat memang dibentuk dalam rangka mensukseskan tujuan membuat Kabupaten Banyuwangi dan masyarakatnya menjadi sehat. Kegiatan kemasyarakatan yang direncanakan konsisten dengan indikator tatanan.

Untuk mengukur keberhasilan masing-masing pokja dalam mengaplikasi tatanan kabupaten sehat, dicanangkan pemberian awarding atau penghargaan atas prestasi yang telah dipertahankan, dimana indikator yang dipakai adalah tatanan permukiman sehat dan tatanan masyarakat sehat yang mandiri. Setiap RT binaan membuat dokumen kegiatan sesuai tatanan untuk di verifikasi kebenarannya. Kemudian di tingkat Kecamatan yang telah terbentuk FKD/KS telah dibentuk Kelompok Kerja (Pokja) Desa/Kelurahan Sehat. Selain RT, FBS juga menjaring kelompok Karang Taruna dan Perempuan-perempuan berprestasi dalam kegiatan PHBS.

\section{Simpulan}

Dokumen Verifikasi Penyelenggaraan Kabupaten/Kota Sehat Tahun 2020 di Kabupaten Banyuwangi yang merupakan salah satu cara untuk mewujudkan Banyuwangi yang bersih, nyaman, aman dan sehat dihuni penduduk, yang dicapai melalui terselenggaranya penerapan beberapa 
tatanan dengan kegiatan yang terintegrasi disepakati masyarakat dan Pemerintah Daerah yang telah dilaksanakan semua komponen masyarakat di Kabupaten Banyuwangi baik sektor pemerintah, swasta, dan masyarakat. Kegiatan selama pandemi covid 19 ini kegiatan masyarakat di tingkat kecamatan dan kelompok kerja didominasi oleh kegiatan sosial pembagian masker, hand sanitasier, dan penyemprotan disinfektan.

\section{Referensi}

BPS. 2020. Kabupaten Banyuwangi Dalam Angka 2020. https://banyuwangikab.bps.go.id/publication/2020/02/28/00e63a1e 4d39071af957721e/kabupaten-banyuwangi-dalam-angka-2020-penyediaan-data-untuk-perencanaan-pembangunan.html

Forum Banyuwangi Sehat. 2020. Dokumen Verifikasi Provinsi 2020. Banyuwangi, FBS.

Forum Gambiran Sehat. 2020. Dokumen Kegiatan 2020. Gambiran, FKKS.

Forum Komunikasi Genteng Sehat. 2020. Dokumen Kegiatan 2020. Genteng, FKKS.

Forum Komunikasi Kecamatan Rogojampi. 2020. Dokumen Kegiatan 2020. Rogojampi, FKKS.

Forum Komunikasi Kecamatan Licin. 2020. Dokumen Kegiatan 2020. Licin, FKKS.

INAYAH, Nurul et al. Pemberdayaan Masyarakat Dalam Usaha Peningkatan Pendapatan Keluarga Sejahtera (UPKKS). LOYALITAS, Jurnal Pengabdian Kepada Masyarakat, [S.l.], v. 2, n. 1, p. 112-123, may 2019. ISSN 2621-4687. Available at: <http://ejournal.iaida.ac.id/index.php/loyal/article/view/409>. Date accessed: 15 dec. 2020.

Jauhariyah, N. (2019). Halal Friendly Tourism Policy In Banyuwangi. Proceedings of Annual Conference for Muslim Scholars, 3(1), 81-89. Retrieved from http://proceedings.kopertais4.or.id/index.php/ancoms/article/view/2 22 
Jauhariyah, Nur Anim dkk. Disparitas Antar Kecamatan Dan Strategi Pembangunan Ekonomi di Kabupaten Banyuwangi. diakses 16 Agustus 2019. http://jurnal.unissula.ac.id/index.php/cbam/article/view/170/0

JAUHARIYAH, Nur Anim. Kebijakan Pengentasan Kemiskinan Melalui Kajian Potensi Sektor Basis Di Kabupaten Banyuwangi. Jurnal Darussalam: Jurnal Pendidikan, Komunikasi dan Pemikiran Hukum Islam, [S.l.], v. 7, n. 1, p. 112-126, sep. 2015. ISSN 2549-4171. Available at: $<$ http://ejournal.iaida.ac.id/index.php/darussalam/article/view/54>. Date accessed: 15 dec. 2020.

Kabupaten Banyuwangi. 2020. Data Persebaran Penduduk. https://www.banyuwangikab.go.id/profil/kependudukan-dannaker.html

Kabupaten Banyuwangi. 2020. Prestasi dan Penghargaaan Kabupaten Banyuwangi. https://www.banyuwangikab.go.id/profil/prestasipenghargaan.html

Peraturan Bersama Menteri Dalam Negeri Dan Menteri Kesehatan Nomor 34 tahun 2005 nomor: 1138/MENKES/PB/VIII/2005 Tentang Penyelenggaraan Kabupaten/Kota Sehat Dengan Rahmat Tuhan Yang Maha Esa Menteri Dalam Negeri Dan Menteri Kesehatan. Diakses pada 20 Agustus 2019 http://jdih.surakarta.go.id/jdihsolo/proses/produkhukum/file/2219P ERMEN_34_2005_PENERBIT_PDF\#: :text=Pengertian,1.,disepakati\%20masyarakat\%20dar\%2C\%20pemerintah\%20daerah. 2005:444 